\title{
METHODS
}

UDC 543.51:543.544.3+577.115.3

doi: https://doi.org/10.15407/ubj89.03.046

\section{GC/MS ANALYSIS OF TREMELLA FUCIFORMIS (WHITE JELLY MUSHROOMS) OIL}

\author{
REGINALD C. OHIRI \\ Department of Biochemistry, Faculty of Science, University of Port Harcourt; \\ East-West Road, Choba, Rivers State, Nigeria; \\ e-mail: raycohiri@yahoo.com,reginald.ohiri@uniport.edu.ng.
}

The use of mushrooms for the treatment of diseases can be traced to Paleolithic era. One mushroom that has shown potent medicinal properties both by oral consumption and topical application is the Tremella fuciformis. GC/MS analyses of T. fuciformis oil obtained by hydro-distillation showed four predominant compounds. 9,19-Cyclolanost-24-en-3-ol, (3.beta.)- was the most predominant with $R_{T}$ of 20.766 and $24.672 \mathrm{~min}$ and a percentage total of 32.681 followed by 7-Isopropenyl-1,4a-dimethyl-4,4a,5 ,6,7,8-hexahydro-3H-naphthalen-2-one with $R_{T}$ of $22.425 \mathrm{~min}$ and a percentage total of 21.334 , lupeol had $R_{T}$ of 22.825 and $23.230 \mathrm{~min}$ and a percentage total of 18.531, while lanosterol had $R_{T}$ of 21.079 and $23.034 \mathrm{~min}$ and a percentage total of 17.845. These four compounds represent $90.391 \%$ of the total constituent compounds in T. fuciformis oil. The therapeutic properties of two predominant compounds (lanosterol and lupeol) of this mushroom confirm its use for the treatment of both dermatological and ophthalmological related diseases by traditional medical practitioners.

Ke y words: mushrooms Tremella fuciformis, GC/MS analysis, volatile components, lipids, triterpenoid.

$\mathrm{F}$ ruiting bodies of non-poisonous giant mushrooms are consumed either because of their nutritional properties or their medicinal benefits. Mushrooms have a long and rich medicinal history. For example, the Paleolithic people knew and used mushroom as medicines for the treatment of disease [1]. Apart from the use of mushrooms in traditional medicine, mushroom extracts are presently applied in modern medicine in most Asian countries. Most of their extracts, such as polysaccharide, glycoprotein and proteoglycans are presently under basic research for their potential to modulate immune system responses and inhibit tumor growth [2], whereas other isolates have shown potential antiviral, antibacterial, anti-parasitic, anti-inflammatory and antidiabetic properties in preliminary studies [3]. Medicinal properties of most mushrooms are exhibited either by oral consumption of the whole mushroom or its extract. $T$. fuciformis is one mushroom that has shown potent medicinal properties both by oral consumption and topical application. This mushroom has enjoyed a long dermatological history as a skin tonic for healthy complexion, it's used in traditional Chinese medicine for the treatment and management chronic tracheitis, asthma and other cough-related conditions has been reported [4]. Though studies revealed Glucuronoxylomannan and Vitamin D as the two bioactive constituents of this mushroom, its blood glucose and cholesterol lowering ability and anti-tumor properties are being studied [4]. This present study is geared towards the determination of possible therapeutic secondary metabolites whose presence may have also contributed to some of the medicinal potentials of this mushroom.

\section{Materials and Methods}

Sample collection and preparation. Fresh T. fuciformis was obtained from its natural environment

\footnotetext{
(C) 2017 Ohiri R. C. This is an open-access article distributed under the terms of the Creative Commons Attribution License, which permits unrestricted use, distribution, and reproduction in any medium, provided the original author and source are credited.
} 
(dead mango tree stump) in Ikeduru Local Government Area of Imo State, South-East Nigeria. A quantity of the the mushroom $(2.5 \mathrm{~kg})$ was thoroughly washed with distilled water and air dried for a period of 2 weeks in a clean dust free environment. The dried samples were ground using a Thomas Scientific, (Model 4) Wiley's mill until a fine smooth powder was obtained.

GC/MS analysis of mushroom oil. The ground mushroom powder (100 g) was added to $3.0 \mathrm{dm}^{3}$ of distilled water and the oil obtained by hydro-distillation was collected into hexane. The solution was concentrated by evaporation at room temperature. The oil was analysed using a combined gas chromatograph model HP 6890 and mass spectrometer model 5973 (AgilentTech.) fitted with a capillary column HP-5 MS (5\% phenylmethylsiloxane) $30.0 \mathrm{~m} \times 250 \mu \mathrm{m} \times 0.25 \mu \mathrm{m}$, using helium as a carrier gas at initial column temperature $120^{\circ} \mathrm{C}$ for $5 \mathrm{~min}$. Thereafter, the column temperature was increased at $5{ }^{\circ} \mathrm{C}$ per minutes to $320^{\circ} \mathrm{C}$ and held for $5 \mathrm{~min}$. Electron impact ionization for mass spectroscopy was done at ionization energy of $70 \mathrm{eV}$. The essential oil was diluted with $98 \%$ hexane and $2 \mu 1$ of the diluted sample was automatically injected into AgilentTech model 5973 mass spectrometer. The constituent compounds were identified using the Chem-Office software attached to the MS library. The names, molecular formulas, molecular weights and structures of the component oils were ascertained using the database of National Institute Standard and Technology (NIST).

\section{Results and Discussion}

The five constituent oils from T. fuciformis, their gas chromatogram, spectra and structures are shown in Table and Fig. 1-6 respectively. The four predominant oils identified are 9,19-Cyclolanost-24-en-3-ol, (3.beta.)- with $\mathrm{R}_{\mathrm{T}}$ of 20.766 and $24.672 \mathrm{~min}$ and a percentage total of 32.681, 7-Isopropenyl-1,4a-dimethyl-4,4a,5 ,6,7,8-hexahydro-3Hnaphthalen-2-one with $\mathrm{R}_{\mathrm{T}}$ of $22.425 \mathrm{~min}$ and a percentage total of 21.334, Lupeol with $\mathrm{R}_{\mathrm{T}}$ of 22.825 and $23.230 \mathrm{~min}$ and a percentage total of 18.531 and Lanosterol with $\mathrm{R}_{\mathrm{T}}$ of 21.079 and 23.034 min and a percentage total of 17.845. These four oils represent $90.391 \%$ of the total constituent oil in T. fuciformis. 2(1H)Naphthalenone,3,5,6,7,8,8a-hexahydro-4,8a-dimethyl-6-(1-methylethenyl)- was the least compound identified in this mushroom with $\mathrm{R}_{\mathrm{T}}$ of $22.560 \mathrm{~min}$ and a percentage total of 9.609 .

In this present study, the GC/MS analysis of the oil from $T$. fuciformis showed the presence of five compounds. In terms of percentage concentration, 9,19-cyclolanost-24-en-3-ol, (3.beta.)-, acetic acid,7Isopropenyl-1,4a- dimethyl-3-oxo-2,3,4,4a,5,6,7,8octahydronaphthalen-2-yl ester, lupeol and lanosterol were predominant in this mushroom. Although two (9,19-cyclolanost-24-en-3-ol, (3.beta.)- and acetic acid,7-Isopropenyl-1,4a-dimethyl-3-oxo2,3,4,4a,5,6,7,8-octahydro-naphthalen-2-yl ester) of the four major compounds in this mushroom may have served as aromatic and protective compounds, lanosterol and lupeol have shown different therapeutic properties. The double retention time observed

Results of the GC-MS Analysis of the constituent oils from T. fuciformis

\begin{tabular}{|c|l|c|c|c|c|}
\hline S/N & \multicolumn{1}{|c|}{ Compound } & $\begin{array}{c}\text { Retention } \\
\text { time (min) }\end{array}$ & $\begin{array}{c}\text { Percentage } \\
\text { of the total }\end{array}$ & $\begin{array}{c}\text { Molecular } \\
\text { formula }\end{array}$ & $\begin{array}{c}\text { Molecular } \\
\text { weight } \\
\text { (g/mol) }\end{array}$ \\
\hline \multirow{2}{*}{1} & 9,19-Cyclolanost-24-en-3-ol, (3.beta.)- & $\begin{array}{l}20.766 \\
24.672\end{array}$ & 32.681 & $\mathrm{C}_{32} \mathrm{H}_{52} \mathrm{O}_{2}$ & 468.754 \\
\hline 2 & Lanosterol & $\begin{array}{l}21.079 \\
23.034\end{array}$ & 17.845 & $\mathrm{C}_{30} \mathrm{H}_{50} \mathrm{O}$ & 426.710 \\
\hline \multirow{2}{*}{3} & $\begin{array}{l}\text { Acetic acid,7-Isopropenyl-1,4a- } \\
\text { dimethyl-3-oxo-2,3,4,4a,5,6,7,8- } \\
\text { octahydronaphthalen-2-yl ester }\end{array}$ & 22.42 & 21.334 & $\mathrm{C}_{17} \mathrm{H}_{26} \mathrm{O}_{4}$ & 294.390 \\
\hline \multirow{2}{*}{4} & $\begin{array}{l}\text { 2(1H)Naphthalenone, 3,5,6,7,8,8a-hexahydro- } \\
\text { 4,8a-dimethyl-6-(1-methylethenyl)- }\end{array}$ & 22.560 & 9.609 & $\mathrm{C}_{15} \mathrm{H}_{22} \mathrm{O}$ & 218.335 \\
\hline \multirow{2}{*}{5} & Lupeol & $\begin{array}{l}22.825 \\
23.230\end{array}$ & 18.531 & $\mathrm{C}_{30} \mathrm{H}_{50} \mathrm{O}$ & 426.729 \\
\hline
\end{tabular}




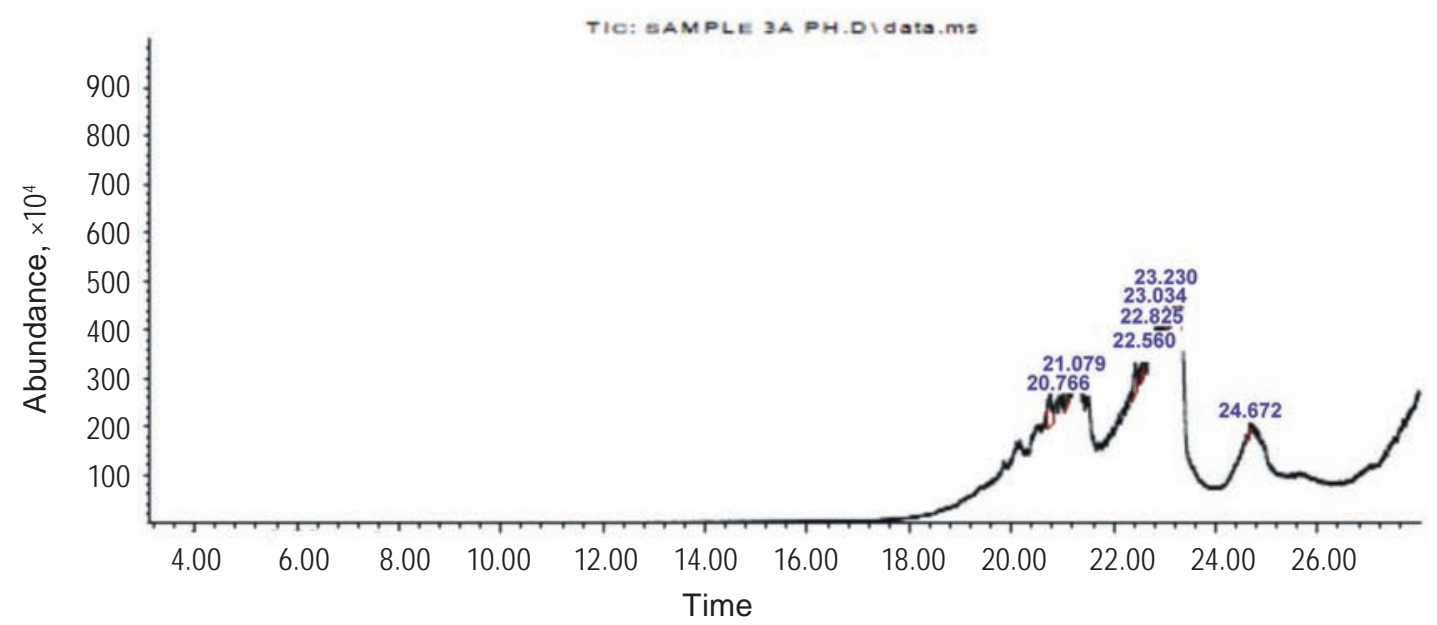

Fig. 1. Chromatogram of volatile components of T. fuciformis

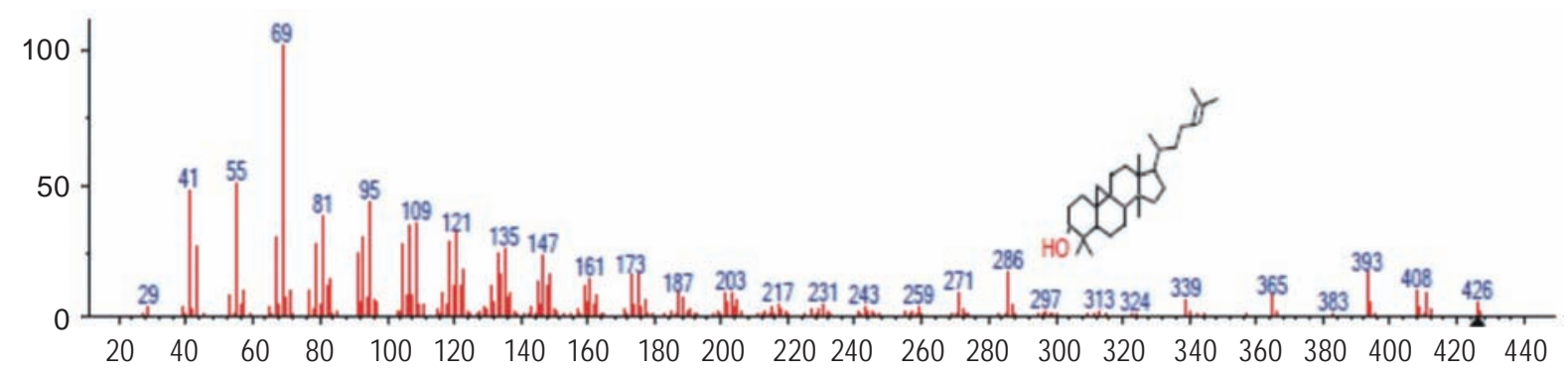

Fig. 2. Mass spectrum of 9,19-cyclolanost-24-en-3-ol, (3.beta.)- ( $R_{T}: 20.766$ and $\left.24.672 \mathrm{~min}\right)$

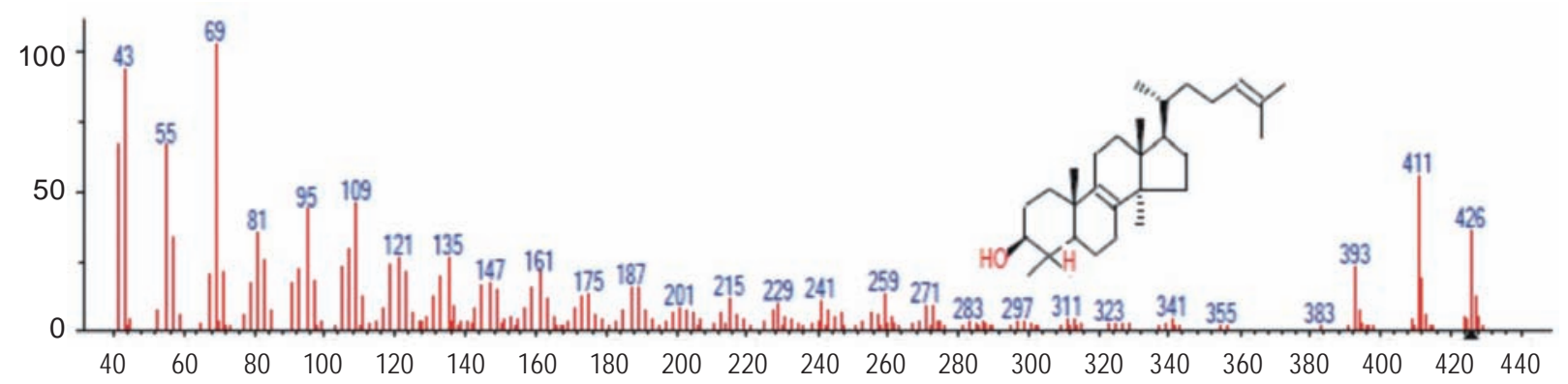

Fig. 3. Mass spectrum of lanosterol ( $R_{T}: 21.079$ and $\left.23.034 \mathrm{~min}\right)$

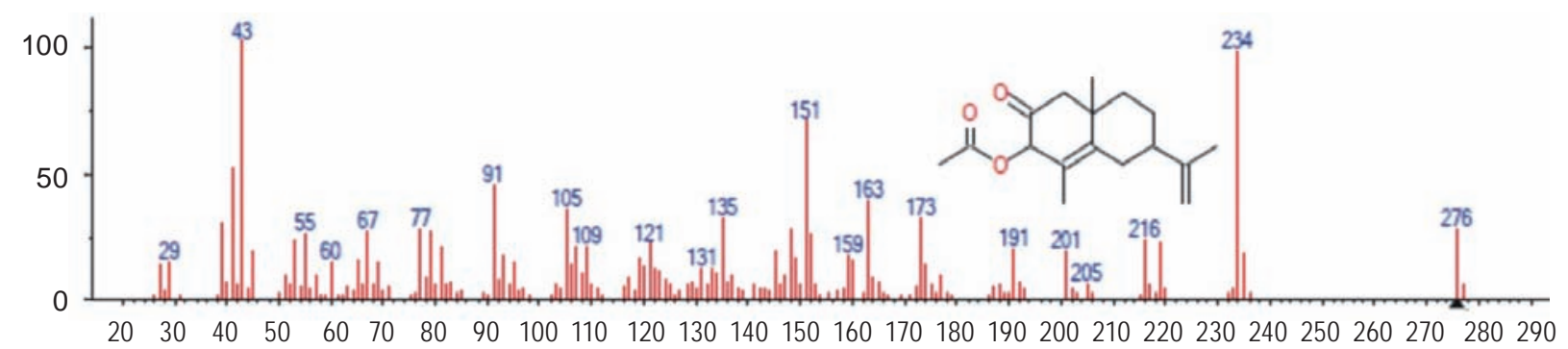

Fig. 4. Mass spectrum of acetic acid. 7-Isopropenyl-1,4a-dimethyl-3-oxo-2,3,4,4a,5,6,7,8-octahydronaphthalen-2-yl ester $\left(R_{T}: 22.425 \mathrm{~min}\right)$ 


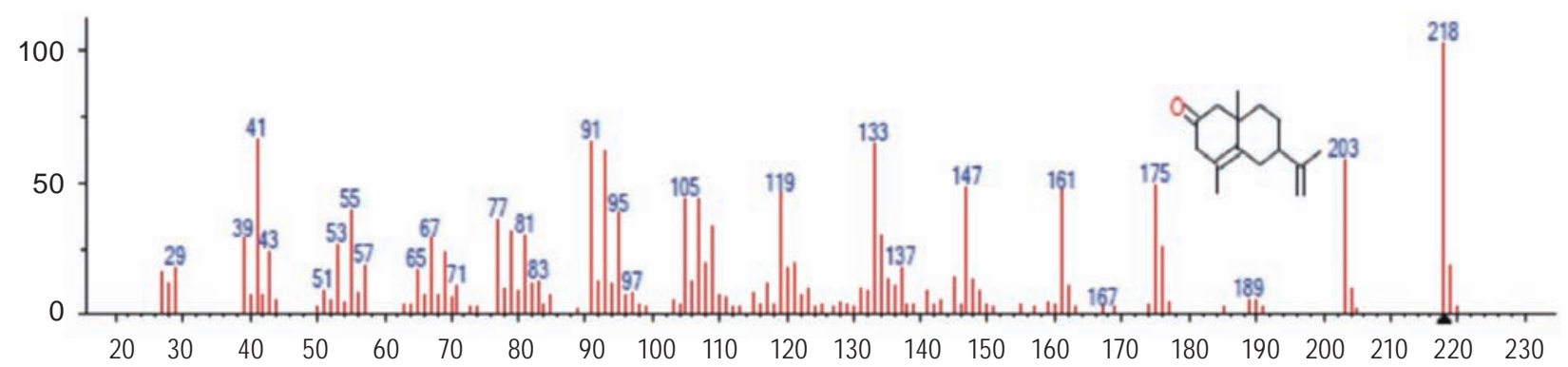

Fig. 5. Mass spectrum of 2(1H)naphthalenone, 3,5,6,7,8,8a-hexahydro-4,8a-dimethyl-6-(1-methylethenyl)$\left(R_{T}: 22.560 \mathrm{~min}\right)$

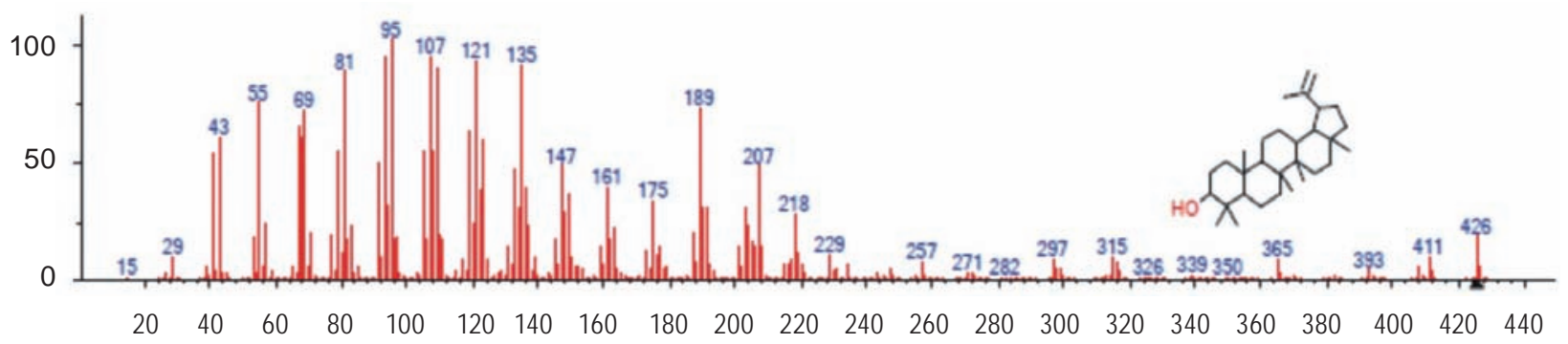

Fig. 6. Mass spectrum of lupeol $\left(R_{T}: 22.825\right.$ and $\left.23.230 \mathrm{~min}\right)$

for 9,19-cyclolanost-24-en-3-ol, (3.beta.)- (20.766 and $24.672 \mathrm{~min}$ ), lanosterol (21.079 and $23.034 \mathrm{~min}$ ) and lupeol (22.825 and $23.230 \mathrm{~min})$ may be as a result of stereoisomerism. A more stable isomer may exhibit a higher retention time than the less stable isomer thereby generating two retention times for mirror images of the same compound.

The high concentration of 9,19-cyclolanost24-en-3-ol, (3.beta.)- observed in this study shows the ability of this mushroom to absorb and accumulate lipid compound from their growth medium. 9,19-cyclolanost-24-en-3-ol, (3.beta.)- is a triterpenoid sterol that is domicile to plants, where it serves as a precursor for the synthesis of other plant steroids [5]. The fairly high concentration of lanosterol observed in this study not only confirms lanosterol as the precursor for the synthesis of steroids in this mushroom, but also shows the ability of this mushroom to synthesize lanosterol via a stepwise process initiated by the enzymatic conjugation of isopentenyl pyrophosphate and dimethylallyl pyrophosphate. Though lanosterol is a tetracyclic triterpenoid, its ability to prevent and reverse cataract formation in dogs and rabbits has being reported [6, 7]. However, a 6 day incubation of age-related cataractous human lens nuclei in lanosterol solution failed to reverse its nuclear opacity [8]. Zhao L. et al., [6] also reported the ability of lanosterol to reduce cataract severity and increase transparency in dissected rabbit cataractous lenses in vitro and cataract severity in vivo in dogs. Their identification of lanosterol as a key molecule in the prevention of lens protein aggregation points to a novel strategy for cataract prevention and treatment [6].

The traditional dermatological application of this mushroom may be as a result of its high lupeol content. As a pharmacologically active phytosterol and triterpene, lupeol has shown antimicrobial, antiprotozoal, antiinflammatory, antitumor and chemopreventive properties [9]. Geetha T., and Varalakshmi P., [10] reported that the use of lupeol causes a $39 \%$ decrease in paw swelling while indomethacin (a conventional anti-inflammatory agent) only reduces paw swelling in rats by $35 \%$. As an antiinflammatory agent, lupeol decreases IL-4 (interleukin 4) production by T-helper type 2 cells $[9,11]$. Though [12,13] reported lupeol as effective inhibitor of both prostate and skin cancers, Marques et al., [14] showed that lupeol at its millimolar concentration can inhibit the activities dipeptidyl peptidase- 4 and prolyloligopeptidase enzymes.

The inhibition of dipeptidyl peptidase- 4 by lupeol indicates that the consumption of this mushroom may induce an oral hypoglycemic effect via 
prolonged incretin effect, which tantamount to a reduction on the incidence of type II diabetes mellitus. The consumption of this mushroom may also be relevant in the reduction of depressive symptoms via lupeol's inhibitory effect on prolyloligopeptidase enzyme. The presence and medicinal importance of these therapeutic triterpenoids observed in this mushroom confirms that the application of this mushroom in the treatment of both dermatological and ophthalmological related diseases by traditional medical practitioners is not limited to its glucuronoxylomannan and vitamin D content.

In conclusion, the two major therapeutic compounds (lanosterol and lupeol) observed in this pioneer GC/MS analysis of this mushroom may be responsible for both dermatological and neutraceutical potentials of this mushroom. This may be as a result of their individualistic effect or a synergetic effect of these triterpenoids and other therapeutic non-volatile compounds that may be present in this mushroom.

\section{ГХ/МС АНАЛІЗ ОЛІЙНОЇ ФРАКЦІї ГРИБIВ TREMELLA FUCIFORMIS (БІЛИЙ ЖЕЛЕПОДІБНИЙ ГРИБ)}

\section{Reginald C. Ohiri}

Department of Biochemistry, Faculty of Science, University of Port Harcourt, East-

West Road, Choba, Rivers State, Nigeria; e-mail: raycohiri@yahoo.com, reginald.ohiri@uniport.edu.ng

Приклади використання грибів для лікування хвороб можна знайти ще в палеоліті. Одним із видів грибів, що виявляють значні лікувальні властивості як за перорального, так і за зовнішнього застосування, є Tremella fuciformis. За допомогою ГX/MC аналізу олійної фракції, одержаної гідродистиляцією iз T. fuciformis, виявлено чотири основні сполуки. Показано, що переважав 9,19-циклоланост24-єн-3-ол, (3ß) з $\mathrm{R}_{\mathrm{T}} 20,766$ і 24,672 хв із загальним вмістом $32,681 \%$. Наступними за процентним вмістом були: 7-ізопропеніл-1,4адиметил-4,4a,5,6,7,8-гексагідро-3Р-нафталін-2-он $(21,334 \%)-\mathrm{R}_{\mathrm{T}} 22,425$ хв; лупеол $(18,531 \%)-\mathrm{R}_{\mathrm{T}}$ 22,825 і 23,230 хв; ланостерол $(17,845 \%)-\mathrm{R}_{\mathrm{T}}$ 21,079 і 23,034 хв. Ці чотири сполуки становили 90,391\% від загальної кількості масляної фракції, одержаної з T. fuciformis. Терапевтичні властивості двох сполук - ланостеролу і лупеолу
- підтверджують застосування T. fuciformis для лікування дерматологічних і офтальмологічних захворювань.

Ключов і слов а: гриб Tremella fuciformis, ГX/MC аналіз, летючі компоненти, ліпіди, тритерпеноїд.

\section{ГХ/МС АНАЛИЗ МАСЛЯНОЙ ФРАКЦИИ ГРИБОВ TREMELLA FUCIFORMIS (БЕЛЫЙ ЖЕЛЕОБРАЗНЫЙ ГРИБ)}

\author{
Reginald C. Ohiri
}

Department of Biochemistry, Faculty of Science, University of Port Harcourt, EastWest Road, Choba, Rivers State, Nigeria; e-mail: raycohiri@yahoo.com, reginald.ohiri@uniport.edu.ng

Примеры использования грибов для лечения болезней можно найти еще в палеолите. Одним из видов грибов, обладающих значительными лечебными свойствами как при пероральном, так и при наружном применении является Tremella fuciformis. C помощью ГМ/MC анализа масляной фракции, полученного гидродистилляцией из T. fuciformis, обнаружено четыре ocновных соединения. Показано, что преобладал 9,19-циклоланост-24-ен-3-ол, (3ß) с $\mathrm{R}_{\mathrm{T}} 20,766$ и 24,672 мин, и общим содержанием $32,681 \%$. Следующими за ним по процентному содержанию были: 7-изопропенил-1,4а-диметил-4,4a,5,6,7,8гексагидро-3Р-нафталин-2-он $\quad(21,334 \%) \quad-$ $\mathrm{R}_{\mathrm{T}} 22,425$ мин; лупеол $(18,531 \%)-\mathrm{R}_{\mathrm{T}} 22,825$ и 23,230 мин; ланостерол $(17,845 \%)-\mathrm{R}_{\mathrm{T}} 21,079$ и 23,034 мин. Эти четыре соединения составляли $90,391 \%$ от общего количества масляной фракции, полученной из T. fuciformis. Терапевтические свойства двух соединений - ланостерола и лупеола - подтверждают применение T. fuciformis для лечения дерматологических и офтальмологических заболеваний.

К лючев ы е слова: грибы Tremella fuciformis, ГХ/MC анализ, летучие компоненты, липиды, тритерпеноид.

\section{References}

1. Hawksworth DL. The magnitude of fungal diversity: the 1.5 million species estimate revisited. Mycol Res. 2001; 105(12): 1422-1432. 
2. Borchers AT, Krishnamurthy A, Keen CL, Meyers FJ, Gershwin ME. The immunobiology of mushrooms. Exp Biol Med (Maywood). 2008; 233(3): 259-276.

3. Lull C, Wichers HJ, Savelkoul HF. Antiinflammatory and immunomodulating properties of fungal metabolites. Mediators Inflamm. 2005; 2005(2): 63-80.

4. Xu W, Shen X, Yang F, Han Y, Li R, Xue D, Jiang C. Protective effect of polysaccharides isolated from Tremella fuciformis against radiation-induced damage in mice. $J$ Radiat Res. 2012; 53(3): 353-360.

5. Schaller $\mathrm{H}$. The role of sterols in plant growth and development. Prog Lipid Res. 2003; 42(3): 163-175.

6. Zhao L, Chen XJ, Zhu J, Xi YB, Yang X, Hu LD, Ouyang H, Patel SH, Jin X, Lin D, Wu F, Flagg K, Cai H, Li G, Cao G, Lin Y, Chen D, Wen C, Chung C, Wang Y, Qiu A, Yeh E, Wang W, $\mathrm{Hu} X$, Grob S, Abagyan R, Su Z, Tjondro HC, Zhao XJ, Luo H, Hou R, Jefferson J, Perry P, Gao W, Kozak I, Granet D, Li Y, Sun X, Wang J, Zhang L, Liu Y, Yan YB, Zhang K. Lanosterol reverses protein aggregation in cataracts. Nature. 2015; 523(7562): 607-611.

7. Groß M. Aggregate aufgelöst. Chemie in unserer Zeit. 2015; 50(2): 83.

8. Shanmugam PM, Barigali A, Kadaskar J, Borgohain S, Mishra DK, Ramanjulu R, Minija CK. Effect of lanosterol on human cataract nucleus. Indian J Ophthalmol. 2015; 63(12): 888-890.
9. Gallo MBC, Sarachine MJ. Biological activities of Lupeol. Inter J Biomed Pharmaceut Sci. 2009; 3: 46-66.

10. Geetha T, Varalakshmi P. Anti-inflammatory activity of lupeol and lupeol linoleate in rats. J Ethnopharmacol. 2001; 76(1): 77-80.

11. Bani S, Kaul A, Khan B, Ahmad SF, Suri KA, Gupta BD, Satti NK, Qazi GN. Suppression of $\mathrm{T}$ lymphocyte activity by lupeol isolated from Crataeva religiosa. Phytother Res. 2006; 20(4): 279-287.

12. Saleem M, Afaq F, Adhami VM, Mukhtar $H$. Lupeol modulates NF-kappaB and PI3K/Akt pathways and inhibits skin cancer in CD-1 mice. Oncogene. 2004; 23(30): 5203-5214.

13. Nigam N, Prasad S, Shukla Y. Preventive effects of lupeol on DMBA induced DNA alkylation damage in mouse skin. Food Chem Toxicol. 2007; 45(11): 2331-2335.

14. Marques MR, Stüker C, Kichik N, Tarragó T, Giralt E, Morel AF, Dalcol II. Flavonoids with prolyl oligopeptidase inhibitory activity isolated from Scutellaria racemosa Pers. Fitoterapia. 2010; 81(6): 552-556.

Received 26.02.2017 